\title{
Gigalologiske strukturer - geologiske processer i store computere
}

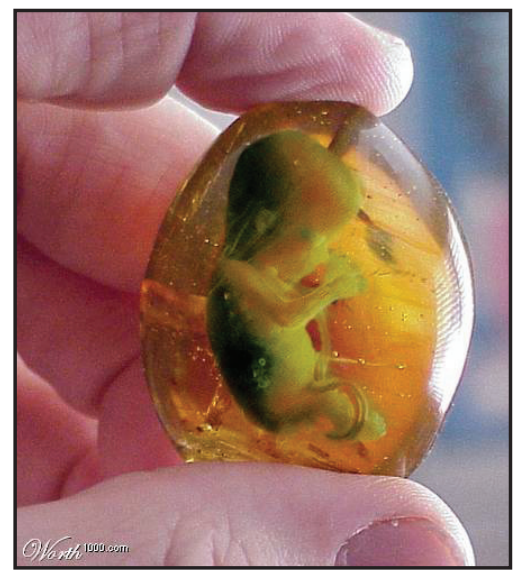

Af geolog Steen Laursen

Naturen danner de smukkeste former i geologien, og geologien former tilbage. De to har i milliarder af år rettet på hinanden som et gammelt ægtepar. Men med introduktionen af kraftige computere er der kommet en ny medspiller i parforholdet.

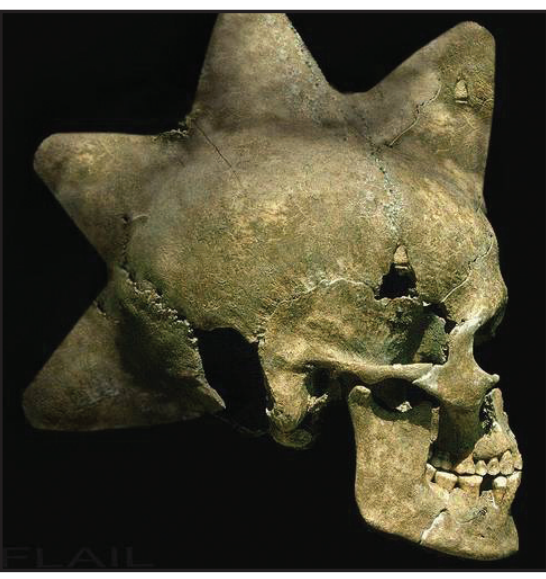

Hvad betyder en vandret streg? Hvad betyder en fold? Strukturerne i geologien fortæller en spændende historie om Jordens liv igennem milliarder af år. Men ikke altid. Nogen gange betyder strukturerne bare, at en kæmpe nørd har moret sig med at hale et billede igennem en avanceret udgave af Photoshop og en voldsomt stor computer.

Sitet “worth1000.com” kører en række konkurrencer, hvor opgaven er at lave en

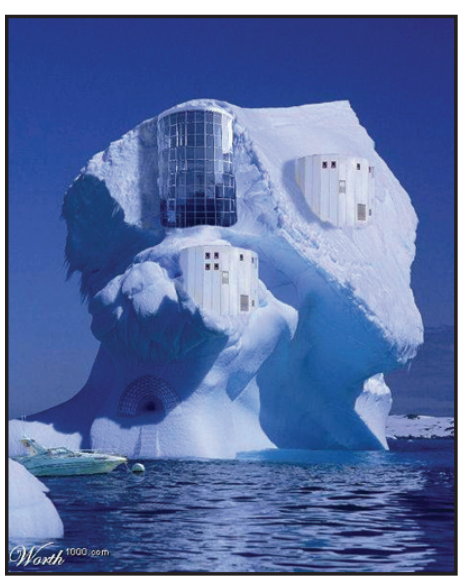

billedmanipulation, som passer til et tema. Derefter lægger de billederne ud på nettet til beundring. GeologiskNyt har kigget en lille del af samlingen igennem og fundet et par gode eksempler på, hvor galt det kan gå.

Billederne bringer vi efter aftale med Worth1000.com, som også tillader, at deres billeder bliver brugt på

GeologiskNyt.dk.
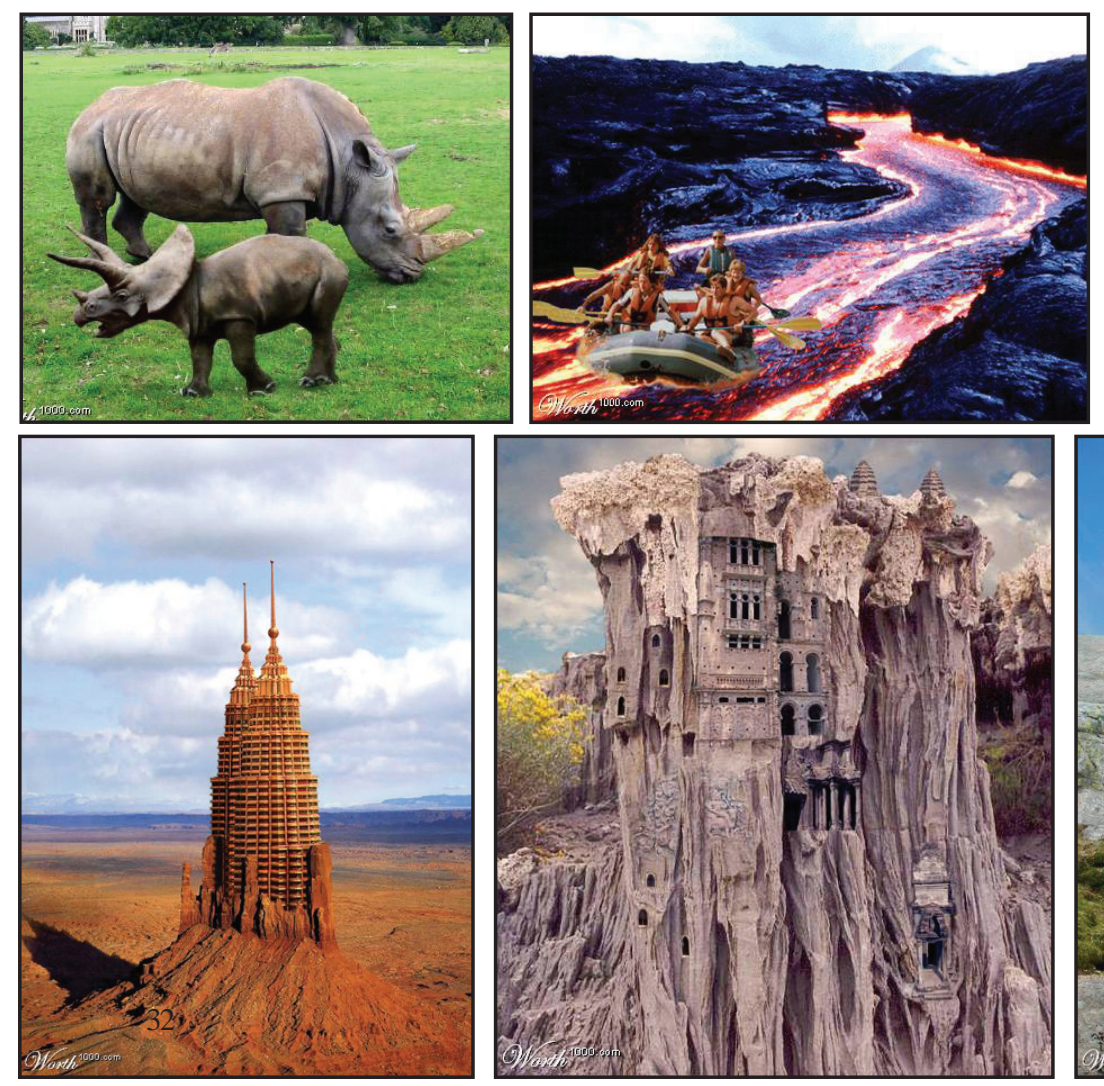
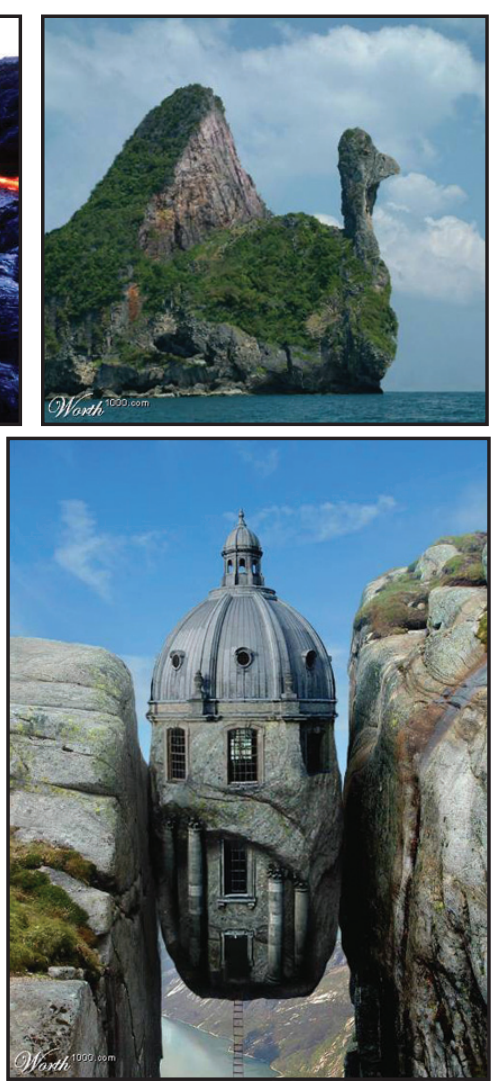
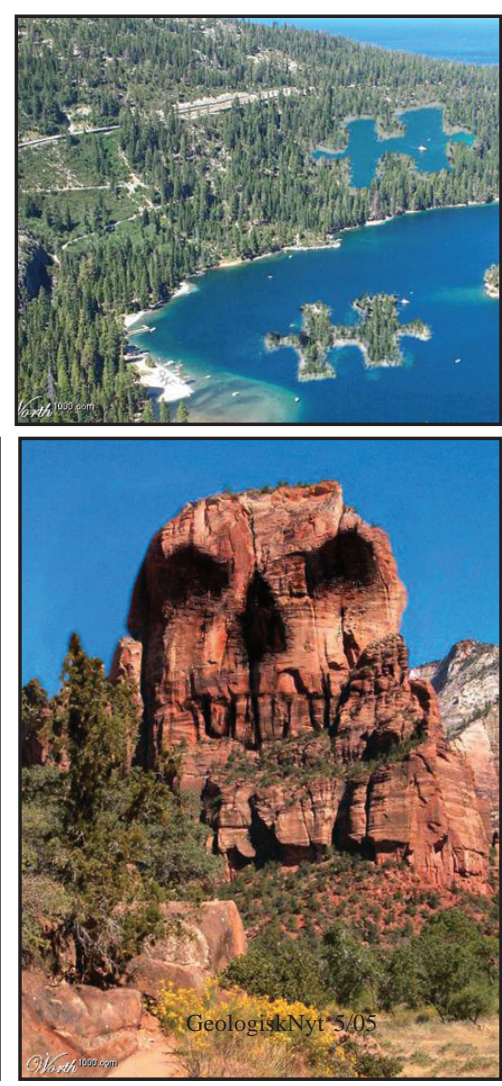